\title{
Peningkatan Kesejahteraan Masyarakat Melalui Konversi Lahan Pertanian ke Kelapa Sawit
}

Zainal Fadri *)

Institut Agama Islam Negeri Batusangkar, Sumatera Barat, Indonesia

E-mail:

zainalfadri@iainbatusangkar.ac.id

\section{Mitria Candra}

Institut Agama Islam Negeri

Batusangkar, Sumatera Barat, Indonesia

E-mail:

$\underline{\text { m.atriyanticandra23@gmail.com }}$

\section{Tegu Chaniago}

Institut Agama Islam Negeri Batusangkar, Sumatera Barat, Indonesia

E-mail:

teguhcaniago11@gmail.com

*) Corresponding Author

\begin{abstract}
Abstrak: Penelitian ini bertujuan untuk menggali informasi dalam peningkatan kesejahteraan masyarakat pasca melakukan konversi lahan pertanian menjadi lahan kelapa sawit. Banyak dari masyarakat desa yang melakukan konversi lahan untuk meningkatkan pendapatan sebagai pemenuhan kebutuhan hidup seharihari, meskipun pada kenyataannya masih tidak semua mereka yang mendapatkan kesejahteraan. Metode yang digunakan dalam penelitian ini adalah kualitatif deskriptif. Penggalian data dilakukan dengan wawancara dan dokumentasi. Wawancara dilakukan dengan petani yang melakukan konversi lahan ke kelapa sawit, pemangku kebijakan dan pemerintah setempat. Hasil wawancara kemudian dilakukan triangulasi dengan dokumentasi yang didapatkan dari penelusuran perpustakaan berupa buku, artikel dan penelitian terdahulu. Hasil dari penelitian ini menunjukkan adanya peningkatan kesejahteraan masyarakat pasca konversi lahan namun dengan aturan yang sangat mengikat baik dari negara maupun dari aturan pasar yang berlaku.
\end{abstract}

\begin{abstract}
This study aims to explore information on improving community welfare after converting agricultural land to oil palm land. Many of the villagers carry out land conversion to increase income as a means of fulfilling their daily needs, although in reality not all of them get welfare. The method used in this research is descriptive qualitative. Data mining was carried out by interview and documentation. Interviews were conducted with smallholders who converted land to oil palm, stakeholders and local government. The results of the interview were then triangulated with documentation obtained from library searches in the form of books, articles and previous research. The results of this study indicate an increase in the welfare of the community after land conversion but with very binding rules both from the state and from the prevailing market rules.
\end{abstract}

Kata Kunci: Kesejahteraan, Masyarakat, Konversi Lahan

\section{PENDAHULUAN}

Kepunahan alam sudah menjadi wacana internasional pada saat ini. Banyak manusia dan negara menjadikan konservasi hutan sebagai salah satu pokok tujuan kinerja negara.
Terutama negara maju yang sudah sangat jauh dari hal yang namanya hidup selaras dengan alam, karena mereka pada dasarnya hidup dalam lingkungan industri dan hanya 
mementingkan profit serta keuntungan praktis semata.

Kepunahan-kepunahan dan kerusakan alam sudah dirasakan oleh sebagian besar penduduk di dunia ini. Negara-negara maju sekarang sedang memikirkan bagaimana mengembalikan suasana alam menjadi seperti semula yaitu alam yang senantiasa memberikan kesejukan atas kehidupan manusia (Fadri, 2020). Alam yang senantiasa mendidik manusia menjadi bersahabat dan hidup di tengah alam. Dari permasalahan ini banyak perumusan-perumusan tentang konservasi alam dan perlindungan hutan sebagai salah satu upaya pelestarian.

Dalam pelestarian alam dan konservasi pertanian ini disinyalir berbarengan dengan prinsip-prinsip etika lingkungan. Manusia hidup selaras dengan alam, memberikan hak alam, dan lain sebagainya dalam meningkatkan kepedulian terhadap alam itu sendiri. Maka untuk mewujudkan itu semua perlu diperhatikan adanya etika lingkungan yang menemani perjalanan panjang ini yaitu mewujudkan alam yang ramah dan hubungan harmonis antara manusia dan alam.

\section{METODE}

Penelitian ini menggunakan metode kualitatif deskriptif dengan tujuan melihat suatu analisa mendalam mengenai peningkatan kesejahteraan masyarakat dalam upaya konversi lahan pertanian ke lahan kelapa sawit. Pengumpulan data dilakukan dengan pendekatan wawancara dan dokumentasi. Wawancara digunakan dalam penggalian data secara mendalam mengenai peningkatan kesejahteraan masyarakat sebelum dan sesudah melakukan konversi lahan ke kelapa sawit serta analisa peran negara dan pasar dalam upaya pemenuhan kesejahteraan masyarakat. dokumentasi digunakan untuk mengecek validasi data yang ditemukan ketika wawancara kemudian melakukan triangulasi untuk validitas (Moleong, 2002). Data yang sudah terkumpul disusun kemudian dilakukan penarikan kesimpulan dan intervensi sehingga menghasilkan sebuah analisa atau penjabaran berupa pembahasan hingga rekomendasi. Data-data dokumentasi didapatkan dari penelusuran penelitian terdahulu, artikel, buku dan makalah mengenai 
konversi lahan perkebunan ke kelapa sawit maupun studi lain yang mendukung penggalian data, sehingga penelitian ini menjadi lebih komprehensif dan mendalam.

\section{HASIL DAN PEMBAHASAN}

Indonesia merupakan salah satu negara agraris atau negara pertanian. Sebagian besar penduduk Indonesia berdomisili di daerah pedesaan dan memiliki mata pencaharian di sektor pertanian. Sektor pertanian merupakan sektor strategis yang berperan penting dalam perekonomian nasional dan kelangsungan hidup masyarakat hingga saat ini, terutama dalam sumbangan terhadap PDB, penyedia lapangan kerja, dan penyediaan pangan dalam negeri. Kesadaran terhadap peran strategis negara sebagai penghasil pertanian menyebabkan sebagian besar dari masyarakat mempertahankan kegiatan pertanian.

Usaha di bidang pertanian terutama padi seharusnya memberikan pemasukan yang sangat besar, karena komoditi padi merupakan bahan pokok yang dikonsumsi oleh masyarakat Indonesia, meskipun kenyataannya banyak petani yang mengalami kerugian jika menanam padi, karena modal yang dikeluarkan tidak sebanding dengan penghasilan dan keuntungan yang didapatkan. Tingginya harga pupuk, bibit dan tenaga kerja mengakibatkan banyak petani yang memilih untuk beralih pada komoditi selain padi, seperti kelapa sawit dan lainnya, yang dirasa lebih banyak menghasilkan keuntungan bagi petani berupa hasil panen (Bhaskara, 2010).

Banyaknya keinginan petani untuk menjadikan alih fungsi lahan pertanian ke lahan kelapa sawit akan berdampak terhadap meluasnya lahan konversi. Area panen merupakan salah satu determinan utama peningkatan produksi padi nasional di samping tingkat produksi tanaman. Pertumbuhan luas area tersebut kadang menjadi persoalan tersendiri bagi daerah yang sedang mengembangkan model komoditi baru seperti kelapa sawit. Seperti di pulau Sumatera yang terlihat saat ini, banyak petani beralih menjadi pengelola lahan sawit baik dalam cakupan mikro ataupun makro pertanian. Pemikiran-pemikiran semacam itu lahir karena banyaknya permintaan pasar terhadap komoditi kelapa sawit yang tentunya sangat 
mengancam produksi pertanian untuk masa-masa yang akan datang.

Faktor-faktor yang menjadikan petani perkebunan melakukan alih fungsi lahan sawit salah satunya karena ada persaingan yang terjadi pada pertumbuhan, industrialisasi dan pembangunan infrastruktur politik. Faktor-faktor yang menentukan konversi lahan pertanian ke komoditi kelapa sawit dikelompokkan menjadi tiga, yaitu faktor ekonomi, faktor sosial dan peraturan pertahanan (Syafa'at, 2001). Faktor ekonomi yang mempengaruhi terjadinya konversi lahan pertanian ke lahan non pertanian adalah (1) nilai kompetitif padi terhadap komoditas lain menurun, (2) respon petani terhadap dinamika pasar, lingkungan, dan daya usaha tani yang mengalami peningkatan. Sementara faktor sosial (Witjaksono, 1996) yang mempengaruhi konversi lahan pertanian ke komoditi kelapa sawit yaitu perubahan perilaku, hubungan dengan pemilik lahan, pengambilan keputusan dan apresiasi pemerintah terhadap apresiasi masyarakat.

Konversi lahan pertanian ke lahan kelapa sawit merupakan persoalan yang menjadi isu dalam kehidupan masyarakat tani, terutama para petani bahan pokok seperti padi, jagung maupun jenis komoditi yang lain. Permasalahan pada konversi lahan akan terasa ketika para penggiat kelapa sawit melaksanakan keputusan untuk melakukan alih fungsi tanpa pertimbangan yang matang atas dampak yang ditimbulkan oleh alih fungsi. Masyarakat terkadang hanya melihat nilai profit yang instan sehingga banyak persoalan yang terjadi ketika perkebunan kelapa sawit telah sampai pada masa panen akhir. Lahan kelapa sawit yang sudah tidak bisa dipanen karena sudah tidak berproduksi dengan baik, akan meninggalkan kondisi tanah yang buruk sehingga tidak dapat diolah dalam waktu yang relatif singkat.

Permasalahan-permasalahan konversi lahan pertanian menjadi lahan kelapa sawit semestinya menjadi sorotan bagi pemerintah maupun bagi pihak pengelola. Masyarakat petani terkadang jarang memikirkan dampakdampak lingkungan yang ditimbulkan akibat konversi lahan kelapa sawit karena minimnya pengetahuan. Petani lebih cenderung mengikuti permintaan pasar yang dianggap sebagai komoditi 
dengan keuntungan yang besar, pencaharian dan sekaligus menjadi begitupun sebaliknya pasar juga dapat konsumsi sehari-hari.

mempermainkan harga dalam Situasi persaingan pasar terutama mencapai keuntungan yang besar komoditi untuk kelapa sawit sehingga persoalan-persoalan diperkirakan akan dapat menciptakan lingkungan, sosial maupun politik mekanisme untuk mempertemukan mewarnai kehidupan lahan sawit yang banyak kepentingan-kepentingan menggiurkan, maka masalah-masalah individu dan kepentingan masyarakat sosial bermunculan dan harus segera (Penny, 1990). Kepentinganmendapat penyelesaian.

\section{Peranan Pasar dalam Konversi Lahan Pertanian ke Lahan Kelapa Sawit}

Peranan pasar dalam konversi lahan pertanian ke lahan kelapa sawit sangat terlihat berupa intervensi komoditi terhadap keinginan petani dalam mencapai kesejahteraan. Minimnya pendidikan yang diterima oleh petani, konversi lahan pertanian menjadi lahan kelapa sawit tidak menjadi persoalan. Tingginya permintaan pasar atas komoditi kelapa sawit membuat para petani hilang kendali dalam mengelola lahan pertaniannya. Banyak petani yang menyewakan pada perusahaanperusahaan sawit berskala besar untuk mengolah lahan pertanian yang sebelumnya menjadi pokok mata kepentingan yang akan mencuat seperti banyaknya model-model penipuan serta politik-politik palsu dalam proses penentuan harga, kesepakatan dan lainlain. Tekanan pasar sangat kuat menjadikan masyarakat atau petani tidak berdaya, sehingga banyak keluhan-keluhan yang terdengar ketika komoditi kelapa sawit mengalami penurunan harga. Masyarakat tidak dapat berbuat apa-apa karena kesepakatan yang telah dilakukan dengan pihak-pihak pengelola lahan kelapa sawit.

Masyarakat atau petani berada dalam kesulitan apabila tekanan dan intervensi pasar sangat kuat dalam menentukan produksi dan hasil panen dengan harga yang terkadang tidak tetap. Harga pasar biasanya akan melemah ketika musim panen tiba, sehingga memungkinkan masyarakat 
mengalami kerugian jika dibandingkan dengan harga-harga stabil sebelum masa panen. Intervensi pasar semacam itu menjadi kendala bagi hubungan petani dan lingkungan maupun sosial.

Petani sebagai pemilik lahan pertanian sebelumnya hanya menjadi alat bagi perusahaan dan pengelola komoditi kelapa sawit dalam menguasai sebagian lahan mereka. Setelah lahan tersebut selesai digarap dengan artian telah berada pada kerusakan, maka yang menanggung dampak adalah petani dan pemilik lahan yang kecil kemungkinannya untuk dapat dijadikan sebagai lahan pertanian kembali. Dalam persoalan ini pasar sangat berperan penting dalam proses terjadinya konversi lahan pertanian ke lahan kelapa sawit. Peranan pasar yang sangat terlihat ketika harga komoditi kelapa sawit yang dapat dipermainkan dengan mudah dalam rangka membangkitkan semangat para petani untuk mengalihfungsikan lahan mereka ke komoditi kelapa sawit yang sebelumnya merupakan lahan pertanian juga tidak kalah dengan keuntungan profit yang ditawarkan.

\section{Peranan Negara dalam Konversi Lahan Pertanian ke Lahan Kelapa Sawit}

Negara merupakan suatu legitimasi yang menentukan arah kebijakan dan mendasari pola kehidupan serta interaksi masyarakat yang akan selalu berhadapan dengan skema etis dalam setiap keputusan yang diambil (Suseno, 1992). Persoalan konversi lahan pertanian ke kelapa sawit merupakan langkah awal dari bentuk keputusankeputusan yang diambil dalam legitimasi negara untuk menentukan arah nasib rakyat dalam jangka menengah dan dalam jangka panjang. Tugas negara adalah mengontrol kehidupan dan proses yang dijalani masyarakat dalam upaya pencapaian kesejahteraan, sehingga peran negara sangat sentral terhadap persoalan konversi lahan pertanian ke lahan kelapa sawit.

Melihat dari dampak-dampak yang ditimbulkan oleh konversi lahan pertanian ke lahan komoditi kelapa sawit, baik dampak positif maupun dampak negatif menjadi landasan dalam suatu negara untuk melaksanakan pengkajian dengan melihat kondisi-kondisi yang terjadi 
saat ini. Persoalan kekinian yang harus ditanggulangi merupakan kewajiban negara sebagai pemegang legitimasi dalam pengertian etis, yaitu jangan sampai kebijakan negara hanya mendapat pasokan dari segi-segi atau hal-hal yang bersifat pragmatis (Yustika, 2003), karena keputusan yang bersifat pragmatis hanya akan menimbulkan dampak yang lebih serius dalam jangka waktu yang lama.

Peran pemerintah dalam menanggulangi persoalan yang terjadi karena konversi lahan pertanian ke lahan komoditi kelapa sawit adalah sebagai pengontrol dan melakukan pendampingan terhadap para petani maupun pengelola lahan kelapa sawit. Jauh dari itu negara juga berkewajiban untuk melakukan pertimbanganpertimbangan terhadap keputusan pemilik lahan untuk mengalihfungsikan lahannya menjadi lahan kelapa sawit. Negara wajib melindungi petani dari tipuan-tipuan pengelola lahan (dalam skala besar) seperti perusahaan-perusahaan kelapa sawit yang bersifat merugikan pemilik lahan. Pemilik lahan pertanian rata-rata hanya memikirkan keuntungan dalam jangka pendek seperti yang terlihat pada kaum pragmatis ekstrim. Masyarakat petani sering tidak memperhatikan dampak jangka panjang yang ditimbulkan oleh kegiatan konversi lahan sehingga persoalan-persoalan sosial sering muncul dalam hal ini.

Negara sejatinya melakukan penelusuran dan pengkajian atas lahanlahan dan kondisi pertanian yang akan di jadikan lahan kelapa sawit. Kondisi tanah yang subur dan cocok untuk lahan pertanian dirasa tidak tepat jika dijadikan sebagai lahan sawit, karena efek buruk yang ditimbulkan pasca panen kelapa sawit yang sangat miskin dengan unsur hara tanah. Kerusakan tanah akan menghambat perkembangan pertanian selanjutnya dan menimbulkan krisis serta kelangkaan bahan pangan.

Kelangkaan bahan pokok disebabkan oleh semakin menyempitnya lahan pertanian serta kondisi tanah yang tidak cukup baik untuk ditanami. Swasembada pangan merupakan hal yang perlu diperhatikan oleh pemerintah sebelum mengeluarkan kebijakan dan legalisasi atas konversi lahan pertanian ke lahan komoditi kelapa sawit, karena ketahanan pangan sendiri merupakan 
suatu langkah awal dalam menentukan kesejahteraan yang didapatkan oleh petani penghasil pangan maupun masyarakat dalam arti luas.

\section{Analisis Negara, Pasar dan Kesejahteraan}

Negara yang menempatkan keadilan sosial sebagai ujung dari proses pembangunan akan mengambil kebijakan melalui serangkaian penilaian etis dan rasional (Yustika, 2003). Berbeda halnya dengan pasar yang lebih cenderung pada progress dan kemungkinan profit yang diuntungkan dari setiap kegiatan. Perbedaan titik tolak sangat terlihat jelas meskipun tujuan dari negara dan pasar sama-sama sejahtera.

Kesejahteraan yang diinginkan pasar dan negara merupakan kesejahteraan yang diinginkan masyarakat dalam menjalani kehidupan sebagai warga negara dan sebagai pelaku ekonomi dalam ranah pasar. Warga negara yang baik akan melaksanakan semua kewajiban sebagai warga negara, seperti mematuhi aturan-aturan, membayar pajak dan ikut serta dalam kegiatan kenegaraan, serta menghindari kegiatan yang sejatinya dapat merusak kestabilan negara seperti korupsi, kecurangan dan tindakan anarkistis. Sementara masyarakat sebagai bagian dari pasar akan melakukan tindakantindakan ekonomi yang diharapkan mampu menjadi bagian dan menjaga stabilitas ekonomi.

Kesejahteraan dalam persoalan konversi lahan pertanian ke lahan komoditi kelapa sawit (jika melihat pada segitiga hubungan negara, pasar dan kesejahteraan) merupakan suatu upaya sebagai perwujudan kesejahteraan yang dapat dirasakan petani pemilik lahan maupun pelaksana (perusahaan kelapa sawit) sebagai bentuk dari implikasi eksplorasi lahan dalam memenuhi kebutuhan. Pasar menghadirkan sistem dan tata kelola dengan sedemikian rupa guna mendapatkan keuntungan dan profit yang lebih bersifat pragmatis, sementara dampak yang ditimbulkan oleh konversi lahan jangka panjang kurang diperhatikan sehingga menyusahkan masyarakat petani akibat dari kerusakan tanah dan lahan.

Untuk melihat kesejahteraan pertanian dari intervensi pasar atau negara merupakan hal yang sulit, karena hubungan negara dan pasar 
tidak dapat dipisahkan secara tegas. Negara dan pasar sangat berhubungan erat bahkan terkadang terjadi bias antara negara dan pasar dalam mengupayakan suatu kesejahteraan bagi masyarakat. Konversi lahan pertanian menjadi komoditi lahan kelapa sawit sangat membantu masyarakat untuk menaikkan pendapatan ekonomi dalam waktu yang relatif singkat, namun menimbulkan dampak yang lebih buruk untuk jangka panjang.

Posisi negara dalam persoalan ini menjadi kontrol atas intervensi pasar terhadap konversi lahan yang berakibat pada penyempitan lahan pertanian yang berujung pada kelangkaan pangan di masa yang akan datang. Jadi rekomendasi yang diberikan adalah bagaimana negara mengontrol, mengevaluasi serta memberikan rekomendasi dalam permasalahan alih fungsi lahan pertanian. Keputusan yang diambil tentunya melalui pertimbangan dan penelitian yang telah matang sehingga komoditi kelapa sawit tetap dapat dikembangkan tanpa harus merusak atau mengambil lahan pertanian sebagai persiapan ketahanan pangan di masa selanjutnya.

\section{KESIMPULAN}

Kesimpulan yang dapat ditarik dari penjelasan sebelumnya adalah konversi lahan pertanian menjadi lahan komoditi kelapa sawit dikarenakan banyaknya kemungkinan keuntungan ekonomis yang didapatkan, sehingga masyarakat petani berharap akan mendapatkan kehidupan yang lebih sejahtera dari sebelumnya. Keinginan untuk melakukan konversi lahan dikarenakan banyaknya intervensi dan permintaan pasar sehingga menjadikan kelapa sawit sebagai suatu upaya dalam mendapatkan keuntungan dan profit yang lebih besar tanpa melihat dampak buruk yang ditimbulkan pada jangka panjang. Negara berperan dalam menekan intervensi pasar dengan melakukan pendampingan, evaluasi serta menurunkan kebijakan-kebijakan etis dalam upaya mempertahankan ketersediaan pangan dan kesejahteraan masyarakat pada jangka pendek maupun jangka panjang.

\section{REFERENSI}

Bhaskara, A. Y. dkk., (2010). Pengaruh Transformasi Lahan Pertanian Menjadi Perkebunan Kelapa Sawit terhadap Tingkat Kesejahteraan Petani. Universitas Negeri Malang. 
Fadri, Zainal. (2020). Pembangunan Masyarakat Alternatif Model Democratic Participatory. Alfuad: Jurnal Sosial Keagamaan, 4(2). 27-39.

Fadri, Zainal. (2020). Perubahan Sosial Masyarakat Muslim Pedesaan Pasca Kedatangan Kyai. Komunitas, 11(2). 133142.

Fadri, Zainal. (2020). Perubahan Struktural Fungsional Prostitusi Online dalam Pandangan Talcott Parsons. Resiprokal: Jurnal Riset Sosiologi Progresif Aktual, 2(2). 211-233.

Kartono, K. (2014). Patologi Sosial. Jakarta: PT Raja Gravindo Persada.

Lauer, R. H. (1993). Perspektif tentang Perubahan Sosial (judul asli: Perspective on Social Change, terj. Alimandan, SU.). Jakarta: PT Rineka Cipta.

Marpaung, L. (2008). Asas Teori Praktik Hukum Pidana. Jakarta: Sinar Grafika.

Martono, N. (2010). Pendidikan Bukan Tanpa Masalah: Mengungkap Problematika Pendidikan dari Perspektif Sosiologi. Yogyakarta: Penerbit Gava Media.
Moleong, L. (2002). Metode Penelitian Kualitatif. Bandung: Remaja Rosdakarya.

Penny, D. H. (1990). Kemiskinan; Peranan Sistem Pasar. Jakarta: UI Press.

Suseno, F. M. (1992). Filsafat sebagai Ilmu Kritis. Yogyakarta: Kanisius.

Syafa'at, N. dkk., (2001). Kajian Penyebab Penurunan Produksi Padi Tahun 2001 di Indonesia. Laporan Hasil Penelitian: Analisis Kebijaksanaan Pertanian Respon terhadap Issu Aktual. Badan Penelitian Pertanian, Departemen Pertanian, Bogor.

Witjaksono, R. (1996). Alih Fungsi Lahan: Suatu Tinjauan Sosiologis. Dalam Prosiding Lokakarya: "Persaingan dalam Pemanfaatan Sumberdaya Lahan dan Air, Dampaknya terhadap Keberlanjutan Swasembada Beras. Kerjasama Pusat Penelitian Sosial Ekonomi Penelitian dengan Ford Foundation, Bogor.

Yustika, A. E. (2003). Negara vs. Kaum Miskin. Yogyakarta: Pustaka Pelajar. 